\title{
The Education of Linnie Haguewood
}

\author{
LISA R. LINDELL
}

"TO SEE LINNIE is to be interested in her; to know her is to love her," wrote teacher Dora Donald in 1895. "It is my earnest wish that she will become so well known in our state that the people of Iowa as a body will have this feeling toward Linnie. When they do who can say what may not be accomplished by this dear child." ${ }^{1}$ In the months and years ahead, Linnie Haguewood, blind and deaf since infancy, would indeed become a popular figure with the Iowa public, her story widely spread through newspapers and fundraising appeals. The publicity brought the teenager, dubbed by the press "the Helen Keller of the West," singular educational opportunities and a solid network of friends and benefactors. ${ }^{2}$ It also created a public persona built on media representations and societal expectations.

Recent scholarship on disability and gender in nineteenthand early twentieth-century America sheds helpful light on Haguewood's reality. Like her contemporaries with disabilities, Haguewood contended with having her story construed and shaped by others. Her experiences were a product of the complex mixture of cultural factors and assumptions that typified her era and determined how disability and gender were treated. Within that context, Haguewood's midwestern location and her particular educational and travel experiences and network of

1. Vinton Eagle, 3/15/1895.

2. For examples of the use of this phrase, see Omaha Daily Bee, 11/18/1897; Pella Chronicle, 4/9/1902; New-York Tribune, 8/14/1903; Los Angeles Times, 8/16/1908.

THE ANNALS OF IOWA 72 (Spring 2013). (C) The State Historical Society of Iowa, 2013. 
support make her story distinctive and offer an opportunity to broaden the historical scholarship. ${ }^{3}$

BORN IN IDA GROVE, Iowa, on October 12, 1879, Linnie Haguewood was the second of seven children of day laborer George Haguewood and Emma Hefner Haguewood. An extended illness contracted at the age of 18 months resulted in the total loss of sight and hearing and extreme physical weakness. Haguewood's parents, as future press accounts regularly emphasized, were poor, overworked, and unaware or wary of formal educational options for her. Haguewood thus remained at home, moving east across the state with her family to Delaware County in the mid-1880s. Although she lacked structured training, she acquired a few domestic skills, learning from her mother to crochet, knit, and sew. When Haguewood was 11, William DeCoursey French, founder of a small, privately funded day school for the deaf in Dubuque, and deaf himself, became aware of her case and introduced the family to the manual alphabet, in which each letter is represented by a specific finger position. As words were spelled into her hand, Haguewood gradually learned the system and became familiar with the names of about 300 objects. ${ }^{4}$

3. Works examining the social and cultural constructions of disability in American history include Paul K. Longmore and Lauri Umansky, eds., The New Disability History: American Perspectives (New York, 2001); Catherine J. Kudlick, "Disability History: Why We Need Another 'Other,'" American Historical Review 108 (2003), 763-93; Mary Klages, Woeful Afflictions: Disability and Sentimentality in Victorian America (Philadelphia, 1999); Kim E. Nielsen, The Radical Lives of Helen Keller (New York, 2004); and idem, A Disbility History of the United States (Boston, 2012).

4. Vinton Eagle, 3/15/1895; Cedar Rapids Evening Gazette, 3/19/1898, 2/23/1901; Los Angeles Times, 8/16/1908; Arthur Fry and Jeanie Hickerson, The Genealogy of the Family of Clem Frank Haguewood and His Wives, Effie M. Saunders and Mary Elizabeth Meader (Fayetteville, AR, 1999), 16P-17P. Before founding the Eastern Iowa School for the Deaf in 1888, William DeCoursey French taught at the Indiana Institution for the Deaf and Dumb and was the first principal of the Nebraska Institute for the Deaf and Dumb in Omaha. In 1893 he reported that 18 pupils had attended his Dubuque day school over the past four years. He did not succeed in establishing it as a second state institution for the deaf, and the school, ultimately unable to support itself, closed in 1898. "School Items," American Annals of the Deaf 44 (Jan. 1899), 70; De Coursey French, "The Eastern Iowa School for the Deaf, Dubuque, Iowa," in Histories of the American Schools for the Deaf, 1817-1893, ed. Edward Allen Fay, 3 vols. (Washington, DC, 1893), 3:3-4. 


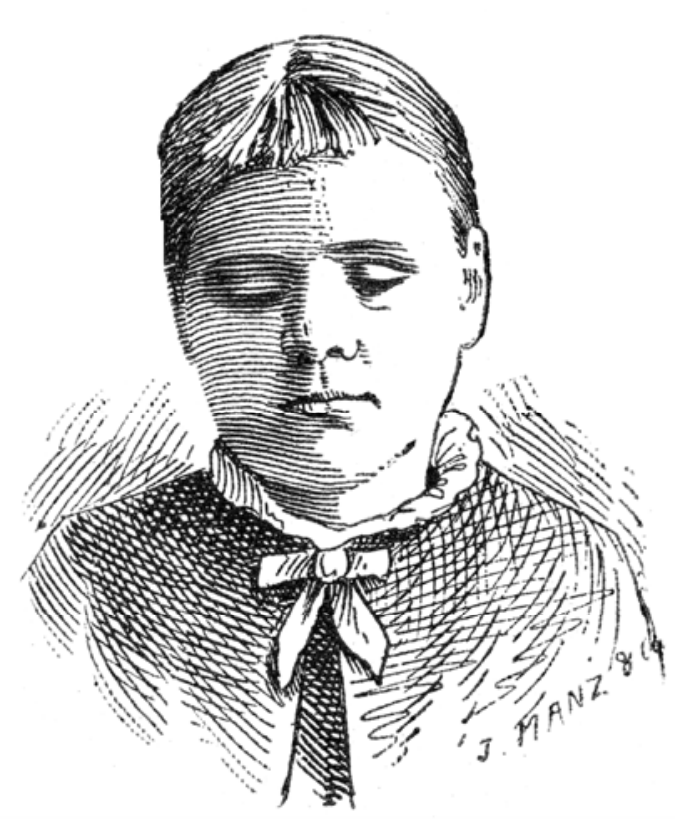

Drawing of Linnie Haguewood at age 11. From William DeCoursey French Collection, RG 1033 AM, Nebraska State Historical Society, Lincoln, Nebraska.

In November 1893 life changed radically for the 14-year-old Haguewood when interested friends persuaded her parents to enroll their daughter in the Iowa College for the Blind in Vinton. The school, approximately 60 miles from her home, was state funded, with families covering clothing, travel, and incidental expenses, if able. An advanced student was assigned to Haguewood as an attendant at a cost of $\$ 1$ per week, paid by William M. Sawyer, a trustee from her home county. She was placed in the kindergarten classes, with the hope that, as Principal Thomas F. McCune stated in his biennial report, she might pick up some fragmentary knowledge. 5

5. "Linnie Haguewood," Twenty-Second Biennial Report of the College for the Blind Located at Vinton, Benton County to the Governor of Iowa (Des Moines, 1895), 33-34 (hereafter cited as Biennial Report, [year]); Vinton Eagle, 3/15/1895; Cedar Rapids Evening Gazette, 3/19/1898; Dora Donald, "Linnie Haguewood: Report to the Iowa State Board of Control," in William Wade, The Deaf-Blind (Indianapolis, 


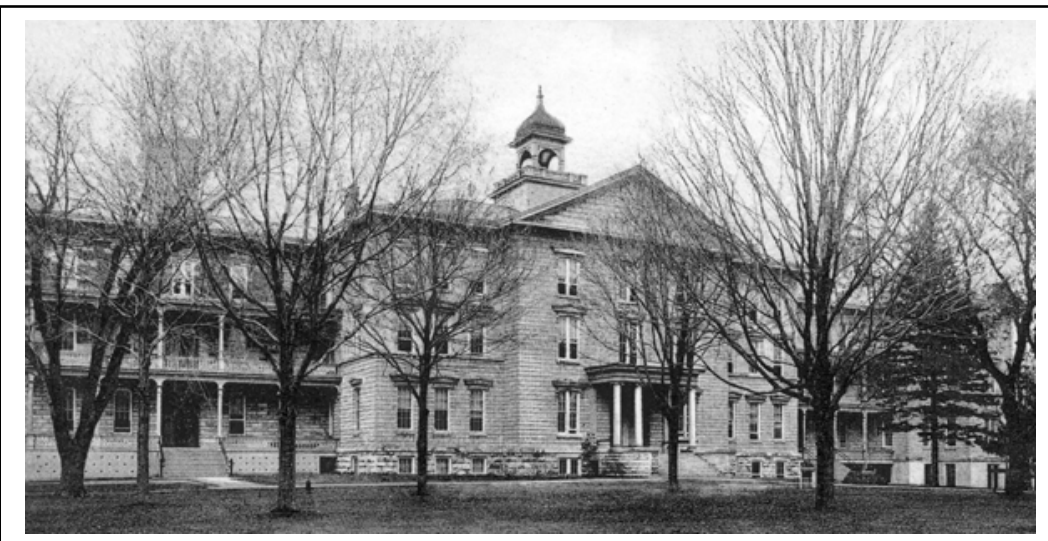

Iowa College for the Blind, early 1900s. Photo courtesy Robert Spangler.

Established in 1853 by the Iowa state legislature as the Asylum for the Blind in Iowa City (then the state capital), the school relocated to Vinton in 1862. During the 1893-94 school year 180 students attended the school, the majority between the ages of 10 and 21, with a nearly equal percentage of males and females. Most, McCune reported, were not entirely blind. As the only student who was both blind and deaf, Haguewood attracted the interest and help of many of the students and teachers. In particular, she captured the heart of primary department instructor Dora Donald. Donald's relationship with Haguewood, spanning nearly a decade, would prove formative for both pupil and teacher. ${ }^{6}$

1901), 40. For a history of the College for the Blind, see Dorothy Petrucci O'Leary and Catherine G. Goddard, Gleanings from Our Past: A History of the Iowa Braille and Sight Saving School, Vinton, Iowa (Vinton, 1984). The yearly per capita cost for the state was $\$ 168.28$, McCune reported in 1893. Biennial Report, 1893, 14. McCune served as principal of the College for the Blind from 1882 to 1906. Clarence Ray Aurner, History of Education in Iowa, 5 vols. (Iowa City, 1920), 5:51.

6. Aurner, History of Education in Iowa, 5:3, 15; Biennial Report, 1893, 19; Biennial Report, 1895, 13. In 1892-93 the Iowa College for the Blind had the seventhlargest student enrollment of the 36 state institutions for the blind, and in 189596 it had the sixth-largest enrollment of 35 institutions reporting. Report of the Commissioner of Education for the Year 1892-93 (Washington, DC, 1895), 2056-59; Report of the Commissioner of Education for the Year 1895-96 (Washington, DC, 1897), 2117-21. See also Biennial Report, 1897, 11. According to 1895-1897 statistics, 38 percent of the students were completely blind. Biennial Report, 1897, 14. 


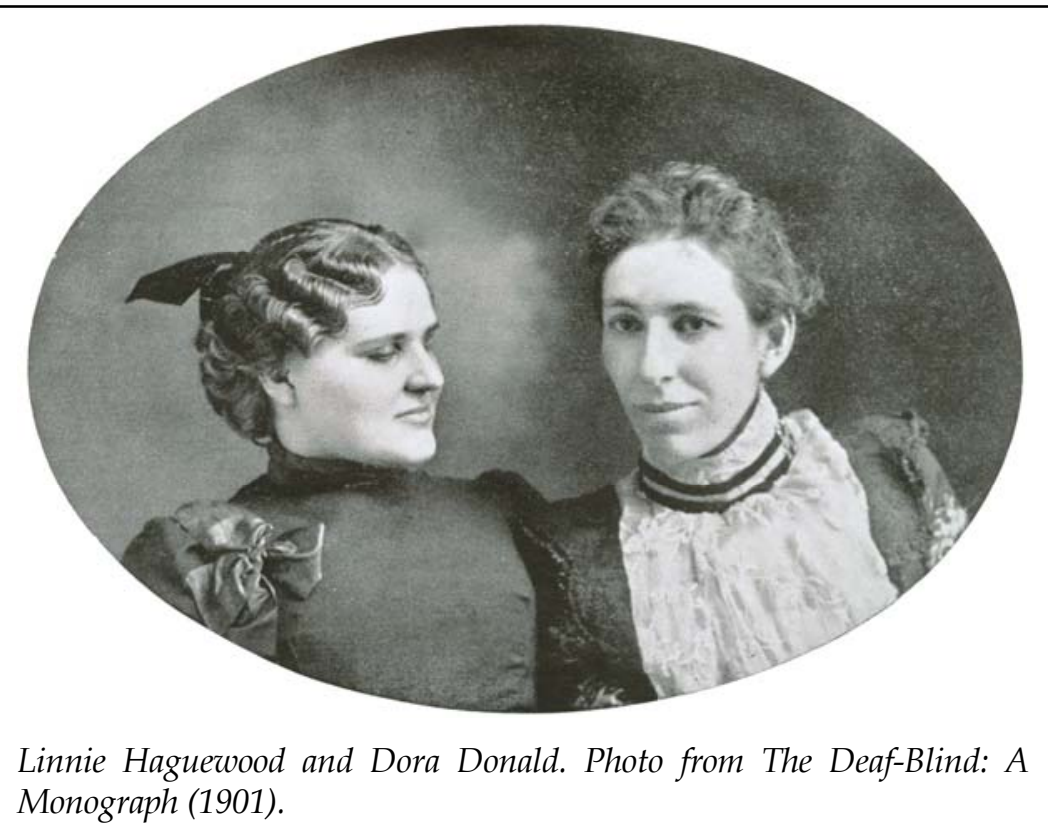

Dora Edith Donald had begun teaching at the Iowa College for the Blind in 1892. Born in 1869 and raised in Kansas and Florida, she taught school at the French Icarian Colony in Adams County, Iowa, before attending the Iowa State Normal School in Cedar Falls in 1891-92. Donald's choice of career may have been influenced by her father's eye condition acquired during his service in the Civil War, which caused partial blindness. ${ }^{7}$

7. Historical Collections of Deuel County [South Dakota], 2 vols. (n.p., 1983), 2:389; Adams County Union, 6/22/1893; Catalog of State Normal School, Cedar Falls, Iowa (1892); Biennial Report, 1893, 5; Civil War Pensions, Donald, Samuel A., Kansas, Regiment 11, Company L, accessed from National Archives and Records Administration. The fourth child and oldest daughter of Samuel and Ellen Norris Donald, Donald was born in Washington County, Kansas, on July 7, 1869. After spending a portion of her childhood in Florida, where her younger sister Ida was born in 1876, and where her mother died, presumably of consumption, she returned to Kansas with her sister in the 1880s to live with an aunt and uncle, and subsequently relocated to Iowa. Ida Donald, like her sister, became an educator of the blind and deaf. She worked, throughout her career, at the Iowa College for the Blind, the South Dakota School for Deaf Mutes in Sioux Falls, and the Colorado School for the Deaf and Blind in Colorado Springs. Manuscript Population Schedule, Lincoln, Washington Co., KS, in U.S., Department of the Interior, Office of the Census, Ninth Census of the United 
Haguewood's progress at the school surpassed McCune's and Donald's expectations. She showed a particular aptitude for sewing, handiwork, and other manual endeavors. In gymnastics class, she began to gain in strength and balance and acquired the ability to walk to her classrooms alone. With the aid of a fellow student, she studied raised print, one of two notational systems taught at the school. Raised print used ordinary alphabet characters, easy for the sighted to decipher but challenging to read tactilely, thus prompting calls for its abandonment in favor of raised dot, or point, systems. New York Point, the other method taught at the school, was developed in the 1860s as an alternative to the Braille dot system and enthusiastically supported by Principal McCune. Braille, though, would ultimately prevail. ${ }^{8}$

In the summer months of 1894, Donald arranged for Haguewood to stay with her for an extended time to work on language and writing skills. During the school year, there were no provisions for specialized instruction, which impelled Donald to action. Haguewood's educational needs had become so imperative, she declared, that they reached beyond the college walls. ${ }^{9}$

States, 1870, National Archives Microfilm Publication M593, roll 542, p. 352; Enterprise, Volusia Co., FL, in U.S., Department of the Interior, Office of the Census, Tenth Census of the United States, 1880, National Archives Microfilm Publication T9, roll 132, p. 387; Center, Riley Co., KS, in 1885 Kansas State Census, roll KS1885_117, p. 22; Biennial Report, 1897, 5; Colorado Springs Gazette Telegraph, 8/25/1907, 6/11/1968.

8. Biennial Report, 1893, 20-21. William Bell Wait of the New York Institution for the Blind pitched his New York Point, in which each character occupied a space two dots high and one, two, three, or four dots wide, as a more efficient system than Braille (first developed in France by Louis Braille in the 1820s, with each character arranged in a cell using the same amount of space, three dots high and two dots wide). Endorsed by the American Association of Instructors of the Blind in 1871, New York Point was widely used in schools for the blind in the latter decades of the nineteenth century. Braille systems persisted and developed, however, including British Braille and American, or modified, Braille, in which the most frequently used letters were assigned the least number of dots, and eventually supplanted New York Point. See B. L. McGinnity, J. Seymour-Ford, and K. J. Andries, "Books for the Blind," Perkins History Museum, Perkins School for the Blind, 2004, accessed Aug. 15, 2012, www.perkinsmuseum.org/section.php?id=200.

9. Vinton Eagle, 3/15/1895; Adams County Union, 7/16/1896; Bernard Murphy, "Linnie Haguewood," Midland Monthly 4 (1895), 45. 
IN MARCH 1895 Donald made an appeal in an article published in the local newspaper, the Vinton Eagle. There and in other writings, Donald presented Haguewood as a captive in need of rescue. Imprisoned in body and mind, she awaited the liberating and enlightening power of education. ${ }^{10}$ Such a perspective reflected common views of the era toward disability, the product, in turn, of a long history and synthesis of interpretation. Interest in the education of the deaf and blind had roots in the eighteenth-century Enlightenment and philosophical speculation on the relationship between the senses and intellectual development. Scientific labels of abnormality and defectiveness, Christian teachings of charity and compassion, reformers' zeal for improvement, and Victorian sentiment all factored into popular attitudes toward disability. Historian Mary Klages, in her study of disability in Victorian America, defines the then prevailing perception as that of suffering beings trapped within afflicted bodies needing to be freed through the earnest efforts of educators. ${ }^{11}$

In her portrait of Haguewood, Donald drew on themes of Victorian children's fiction that exalted model virtues and the role of suffering in building character and instilling empathy. Her depiction of Haguewood's struggles to overcome adversity, her patient suffering, "sweet sunny nature," sense of right and wrong, and innocence fit squarely into the tradition. ${ }^{12}$ Such images, as Donald was certainly aware, suffused the public discourse surrounding America's two most famous deaf-blind students, Laura Bridgman and Helen Keller. Separated in age by half a century, both women were cast in the sentimental role of victim heroine in widely reprinted reports that originated from the prominent Perkins Institution for the Blind in Boston and were composed by Perkins founder Samuel Gridley Howe and his successor and son-in-law Michael Anagnos.

In 1837 Howe had discovered seven-year-old Bridgman while seeking a deaf and blind child upon whom he could test his philosophical theories regarding sensory deprivation, innate

10. Vinton Eagle, 3/15/1895; Donald, "Linnie Haguewood," 42, 47.

11. Klages, Woeful Afflictions, 11, 17.

12. Vinton Eagle, 3/15/1895. See also Klages, Woeful Afflictions, 182-83. 
capacities, and language accession. She entered the Perkins Institution that year and spent most of her time at the school until her death in 1889. Her success in learning language and Howe's active promotion of her accomplishments earned both him and his pupil renown and, from his admiring son-in-law, the appellation "knight-errant of humanity." 13

In his annual reports, Howe stressed Bridgman's isolation and imprisoned state ("a human soul shut up in a dark and silent cell") before her liberation through language. He hailed her educational progress, praising her "insatiable thirst for knowledge" and her moral development. "The different traits of character have unfolded themselves successively, as pure and spotless as the petals of a rose," he wrote, "and in every action unbiased by extraneous influence, she 'gravitates towards the right' as naturally as a stone falls to the ground." Embracing Victorian ideals and language, Howe highlighted Bridgman's "continual gladness - her keen enjoyment of existence-her expansive loveher unhesitating confidence-her sympathy with suffering-her conscientiousness, truthfulness, and hopefulness." 14

Charles Dickens, consummate creator of tales of pathos and redemption and of such heroines as Little Nell, painted Bridgman in like terms. In his American Notes, he recounted meeting Bridgman at the Perkins Institution in January 1842. "There she was, before me; built up, as it were, in a marble cell, impervious to any ray of light, or particle of sound; with her poor white hand peeping through a chink in the wall, beckoning to some good man for help, that an Immortal soul might be awakened." The help had come, he wrote, and "from the mournful ruin of such

13. Sixtieth Annual Report of the Trustees of the Perkins Institution and Massachusetts School for the Blind for the Year Ending September 30, 1891 (Boston, 1892), 53. For more information on Bridgman, see Ernest Freeberg, The Education of Laura Bridgman (Cambridge, MA, 2001); Elisabeth Gitter, The Imprisoned Guest: Samuel Howe and Laura Bridgman, the Original Deaf-Blind Girl (New York, 2001); Klages, Woeful Afflictions, 118-45; and Samuel Gridley Howe's annual reports on behalf of the trustees of the New-England Institution for the Education of the Blind (Boston, 1838-1842).

14. Sixth Annual Report of the Trustees of the New-England Institution for the Education of the Blind to the Corporation (Boston, 1838), 9; Tenth Annual Report . . . (Boston, 1842), 29; Ninth Annual Report ... (Boston, 1841), 40. 
bereavement, there had slowly risen up this gentle, tender, guileless, grateful-hearted being." 15

Bridgman existed to the public in many ways as an object upon which sentimental ideals and scientific theories were projected. As she grew older, her popularity, based as it was on romanticized images of the child victim heroine, inevitably declined, as did Howe's enthusiastic promotional efforts. Also contributing to Bridgman's fading celebrity was the advent of Helen Keller. 16

Born in 1880, Keller began her education and association with Perkins just as Bridgman was nearing the end of her life in that institution. Michael Anagnos, who had assumed the leadership of the school upon Howe's death in 1876, eagerly stepped up to promote Keller. In 1887 Anagnos recruited recent Perkins graduate Anne Sullivan to teach Keller; and, from 1888 to 1892, the pair spent part of their time at the institution. In writing about Keller, Anagnos employed language surpassing that of his predecessor in effusiveness. In his annual reports, hundreds of pages of which were dedicated to Keller, he proclaimed her "deliverance from the dreadful abyss of blackness and solitude" and described her story as a fairy tale or romance. "Noble aspirations, gentle manners, intense feelings, incessant thinking, native goodness, a passion for learning and self-improvement, a thirst for righteousness and a hunger for holiness," he wrote, "all unite in her to place her far above ordinary mortals. She is a manifestation of loveliness, the personification of generosity, the essence of amiableness." 17

As with Howe, Anagnos's fervent promotional efforts would be transient. The cause of the fracturing of his relationship with Keller and Sullivan was an essay the 11-year-old Keller sent to

15. Charles Dickens, American Notes for General Circulation (Leipzig, 1842), 36.

16. Factoring into Howe's response to Bridgman was what he considered her religious indoctrination. In 1862 she chose to be baptized into the Baptist church. Howe had hoped that Bridgman would instinctively come to embrace religious views similar to his own liberal, Unitarian beliefs. Gitter, The Imprisoned Guest, 141-47, 160-66, 252.

17. Fifty-Seventh Annual Report of the Trustees of the Perkins Institution and Massachusetts School for the Blind for the Year Ending September 30, 1888 (Boston, 1889), 71, 77; Sixtieth Annual Report . . (Boston, 1892), 56, 58. 
Anagnos as a birthday gift. After reprinting Keller's “The Frost King" in his 1891 annual report, Anagnos learned that her story was a close retelling of a published piece called "Frost Fairies." Keller and Sullivan insisted that the plagiarism was unintentional and that Keller must have unconsciously retained the story in her memory after it was read to her, but Anagnos, concerned about his institution's reputation, discontinued his encomiums and enthusiastic support. In her 1903 autobiography, Keller lamented that the incident resulted in the loss "of one of my dearest friends." 18

Keller would graduate from Radcliffe College in 1904 and embark on a long career of active involvement in political and humanitarian efforts, though forever linked in the popular imagination with her disability. Her dramatic "rescue," as symbolized by the story of her sudden grasp of language at the water pump, would continue to shape Keller's public image to the detriment of a deeper appreciation of the fullness and complexity of her life. ${ }^{19}$

Haguewood, with her similarity in disability and age to Keller, was inevitably compared with her counterpart (with Haguewood's case being the "more pitiable" of the two, the Omaha Daily Bee declared). In her 1895 article in the Vinton Eagle, Dora Donald contrasted Haguewood's circumstances with Keller's, emphasizing that Keller had every possible educational advantage, while Haguewood was "left for fourteen years to struggle alone." 20 The publication of the article, with a headline proclaiming Haguewood "the Most Remarkable Child in Iowa," inspired Bernard Murphy, the Vinton paper's editor, to become Haguewood's enthusiastic publicist. Through Murphy's efforts and those of Donald and interested women of Vinton, a committee was formed to raise and administer funds for Hague-

18. Helen Keller, The Story of My Life (New York, 1903), 71. For analysis of the incident, see Kim E. Nielsen, Beyond the Miracle Worker: The Remarkable Life of Anne Sullivan Macy and Her Extraordinary Friendship with Helen Keller (Boston, 2009), 111-23. Another source of friction was Anagnos's stance that Sullivan's teaching methods were merely derivative of Howe's methods rather than original and innovative pedagogy. Nielsen, Beyond the Miracle Worker, 116.

19. Nielsen, Radical Lives of Helen Keller, 1, 141-42.

20. Omaha Daily Bee, 11/18/1897; Vinton Eagle, 3/15/1895. 
wood's education. Murphy, as the committee's treasurer, and Donald, as secretary, worked diligently to promote the cause. ${ }^{21}$

THE GOAL was to raise $\$ 1,500$ (about $\$ 40,000$ in 2012 dollars) to send Haguewood to the Perkins Institution for two years of study. Newspapers around the state quickly picked up Murphy's appeals in the Vinton Eagle. The publicity followed a familiar pattern: the pathetic story of a sorely afflicted girl awaiting release from the grip of mental darkness. An education at the illustrious Perkins Institution would enable "poor little stricken Linnie Haguewood" to overcome "the great desolation that has come upon her young life." The public's generosity would allow her "imprisoned soul to break every possible bar which shuts it from this world of life and sound and beauty." 22

The appeals swiftly ignited widespread interest and a generous response. As donations began to accrue, newspapers enthusiastically reported the amounts raised from their communities: over \$50 from a benefit concert in Marion; \$42.45 from an ice cream supper in Manchester; $\$ 13.61$ collected by a blind farmer in Monroe Township; \$1.18 from a group of Waterloo girls donating their lemonade stand proceeds. Iowa schoolchildren contributed their pennies, nickels, and dimes "to send [Linnie] to school." A long-term inmate of the Fort Madison penitentiary, who had been saving up his earnings, \$12 per year, to seek a pardon, gave a dollar for Haguewood's education and challenged others to contribute liberally as well. At a benefit held in Delhi, in Haguewood's home county, the popular appeal of the sentimental victim heroine was much in evidence. The program included two poetry readings, one featuring a "poor little waif" who overcomes her miserable circumstances and the other a devout child with a grateful heart even upon her death bed. ${ }^{23}$

21. Vinton Eagle, 3/29/1895. Bernard Murphy (1847-1918) became co-owner of the Vinton Eagle in 1876 and sole owner in 1886.

22. Reprinted in Vinton Eagle, 4/16/1895, 3/29/1895; Waterloo Daily Courier, 5/20/1895, 5/22/1895.

23. Marion Register, 6/5/1895; Vinton Eagle, 3/15/1895, 3/29/1895, 4/16/1895, 5/7/1895, 5/28/1895; Northern Vindicator (Estherville), 4/4/1895; Waterloo Daily Courier, 4/10/1895, 5/20/1895, 5/23/1895, 6/10/1895; Daily Iowa Capital, 5/21/1895; Manchester Press, 7/25/1895. 


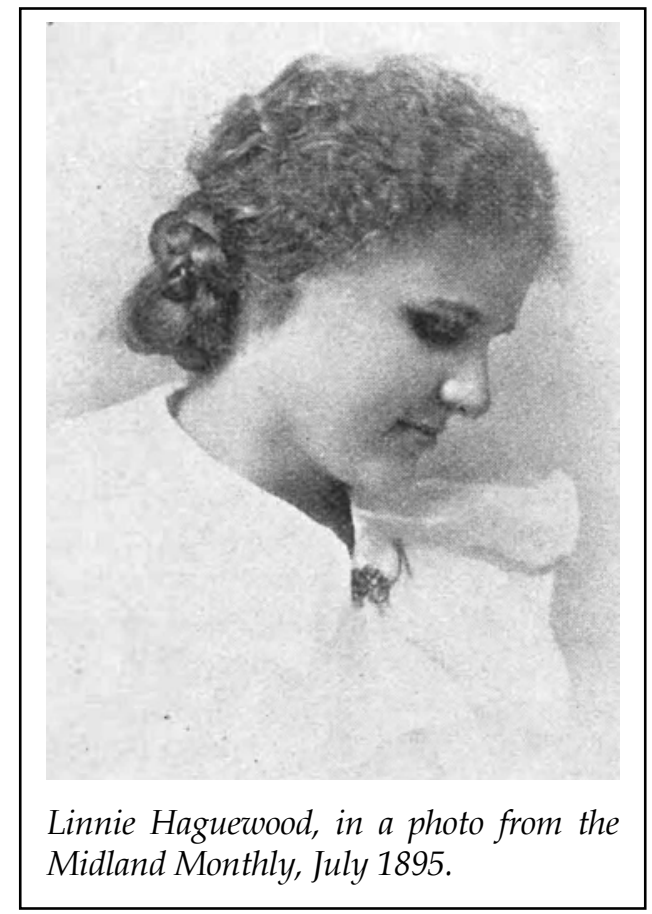

Haguewood herself participated in a number of fundraising events, including an entertainment at the Presbyterian church in Vinton that drew 700 people and another at the music hall in Waterloo. At the latter event, held June 18, 1895, Bernard Murphy, Donald, and Haguewood's mother were present. Murphy announced that Haguewood's education fund now totaled \$1,050; and Haguewood displayed samples of her crocheted handwork, her competence at club swinging (a popular activity in physical education classes of the period), and her developing facility in reading raised print. In reading, as described by the Waterloo Daily Courier, she followed the lines of raised letters with her left hand and with her right spelled out the words that Donald translated to the audience. Also of interest to the crowd was Haguewood's sensitivity to vibrations from movements in the air and ground. ${ }^{24}$

The Iowans present may have experienced this public display by Haguewood as a novelty, but it was not unusual in a

24. Vinton Eagle, 5/28/1895, 5/31/1895; Waterloo Daily Courier, 6/19/1895. 
national context. Exhibitions by students with disabilities were a common occurrence in the era. In the 1840s thousands had come to gaze upon Bridgman, and the practice of exhibiting students and their skills as a means of eliciting sympathy and raising funds continued well into the twentieth century. Haguewood's feelings about the process are unrecorded. ${ }^{25}$

Fundraising efforts continued through the summer. In August the goal was met. Murphy deposited \$1,537.71 with the Farmers' Loan and Trust Co., with every penny donated going into the fund, he reported. The Perkins Institution, though, proved ultimately unattainable. A letter from Perkins director Anagnos informed the committee that the school was at capacity enrollment but assured them that a competent teacher could fully meet Haguewood's educational requirements right where she was in Iowa. At that time, Perkins Institution's student population included three deaf-blind students. All had come prior to Anagnos's falling-out with Keller and Sullivan, however. ${ }^{26}$

Disappointed, but receptive to Anagnos's advice, the committee arranged with the Iowa College for the Blind's board of trustees to have Donald appointed as Haguewood's personal tutor with continued residence at the institution. "This case is one for which the law makes no provision, but is so deserving that your trustees feel they would be censurable if they refused to accede to the request of the committee," the trustees declared in the college's biennial report to the governor. Murphy noted that the plan would have nearly equal advantages to what Perkins could offer, while saving $\$ 350$ to $\$ 400$ per year. In 1896 the Iowa legislature added to the fund, appropriating $\$ 500 .{ }^{27}$

25. Gitter, The Imprisoned Guest, 42, 106; Ernest Freeberg, "The Meanings of Blindness in Nineteenth-Century America," Proceedings of the American Antiquarian Society 110 (2000), 122-29. In his 1899 report, the Iowa College for the Blind's Thomas McCune addressed the topic of public exhibitions: "The easiest way to secure [appropriations]," he wrote, "is to please a legislature with an exhibition of skill on the part of the blind." Such methods were legitimate enough, he concluded, but should be relegated to a secondary place when the future of a school was assured. Biennial Report, 1900, 27.

26. Vinton Eagle, 9/6/1895. Edith Thomas enrolled in 1887, Willie Elizabeth Robin in 1890, and Tommy Stringer in 1891. Wade, The Deaf-Blind, 48, 53-54, 60.

27. “Trustees' Report," Biennial Report, 1895, 8; Vinton Eagle, 9/6/1895; 1896 Laws of Iowa, chap. 146, sec. 1, p. 153. 
HAGUEWOOD'S PRIVATE INSTRUCTION began in September 1895. In her role as teacher, Donald felt a responsibility to speak for Haguewood and act as her advocate. Her publicly available reports used the sentimental style of the day. They are, nonetheless, the prime source and most vital means of following Haguewood's educational progress and provide a window into cultural perceptions relating to disability. Donald, aware of her influence on Haguewood, expressed her desire that her pupil retain her own individuality. "Linnie has a strong character," she wrote, "and I want it to follow its own plan. . . . [I want her to] feel that she is living according to the impulse within her and not as I would have her live." 28

To the satisfaction of both teacher and student, Principal McCune allowed them much freedom at the Vinton school. "A mind so wholly undisciplined could not be confined to the narrow limits of a schoolroom," Donald stated. She described Haguewood's eagerness to satisfy her inquisitive spirit and her ability to do so through the help of her teacher and the use of the manual alphabet. "The halls, the rooms, the yard, boxes, packages, drawers, closets; nothing escaped her diligent fingers." 29

Donald emphasized the difficulty of holding Haguewood's attention during her first few years of instruction. The task required the constant and united effort of both teacher and pupil, Donald wrote, and a "never-yielding determination." In her initial attempts to use prepared educational materials, Donald lamented, the challenges only increased, "for Miss Linnie deliberately went to sleep when I tried some of the beautiful 'book plans' or looked so thoroughly disgusted that I often wondered if she were wiser than I." Ingenuity was often required to keep Haguewood focused and engaged. Gradually, however, Haguewood's growing sense of the wider world and of how words and ideas were formed and expressed through reading and writing incited a zeal to continue learning, her teacher observed. The classroom became more attractive. ${ }^{30}$

28. Reprinted in Sixty-Eighth Annual Report of the Trustees of the Perkins Institution and Massachusetts School for the Blind for the Year Ending August 31, 1899 (Boston, 1900), 123.

29. Donald, "Linnie Haguewood," 41.

30. Ibid., 42; Omaha World Herald, 6/17/1899. 
In teaching Haguewood, Donald followed the method Anne Sullivan had developed to instruct Keller. As Sullivan described her approach, "From the day when Helen first grasped the idea that all objects have names, and that these can be communicated by certain movements of the fingers, I have talked to her exactly as I should have done had she been able to hear, with only this exception, that I have addressed the words to her fingers instead of her ears." ${ }^{31}$ The method differed substantively from Howe's approach with Bridgman, which involved word-by-word memorization.

Donald's aim, as she recorded in the spring of 1896, was to allow her student a free use of the English language by using it in every way possible. Haguewood's language classes consisted of two purely conversational 40-minute sessions per day. "Namewords, verbs, adjectives, pronouns, anything needed, were given," Donald wrote. "She has learned to use language through constant practice, and not through any knowledge of the grammatical rules for its construction." In an address to the Convention of American Instructors of the Deaf in 1898, Donald stated that she had read all that she could find on teaching deaf-blind pupils. Rather than focusing on Haguewood's deafness and blindness, she considered her "a natural child" and endeavored to reach her by talking to her "about everything." 32

As a result, Donald reported, Haguewood's conversational range rapidly increased, leading Haguewood to introduce topics "quite startling in their scope." In addition, books became con-

31. Fifty-Seventh Annual Report (Boston, 1889), 107. In April 1895 John Hitz, superintendent of the Volta Bureau for the Increase and Diffusion of Knowledge Relating to the Deaf (the institution founded in Washington, DC, by Alexander Graham Bell), wrote to Donald after reading her article in the Vinton Eagle. He advised her to follow Sullivan's teaching methods as closely as she could. He also indicated that Sullivan perhaps might be able to take on another pupil if her health allowed, and provided Sullivan's address at the Wright-Humason School for the Deaf in New York City, which Helen Keller attended. Reprinted in Vinton Eagle, 4/30/1895. Keller's autobiography notes that Hitz gave Donald copies of documents relating to Sullivan's work with Keller. Keller, The Story of My Life, 255.

32. Vinton Eagle, 3/27/1896; Cedar Rapids Evening Gazette, 3/19/1898; Proceedings of the Fifteenth Meeting of the Convention of American Instructors of the Deaf, Held at the Ohio Institution for the Deaf and Dumb, Columbus, Ohio, July 28-August 2, 1898 (Washington, DC, 1899), 141. 
stant and beloved companions. All that Haguewood read was a living reality to her and became part of her life, declared her teacher, evoking Sullivan's descriptions of Keller's experience. Besides raised print, Haguewood had learned to use the New York Point. She would soon study Braille as well, learning both American and British Braille, as there was no standardized version until well into the twentieth century. ${ }^{33}$

In learning to write, Haguewood began with New York Point, quickly gaining proficiency after grasping its correlation with the manual alphabet. She next successfully tackled writing with a pencil, learning as many as five letters in half an hour. To write, Haguewood placed a sheet of paper on a grooved board and formed the letters with her pencil in the depressed lines. She employed this method for letter writing. Donald provided samples of her pupil's letters, charting her progress in grammatical composition and complexity of expression. During the summer of 1896, spent at home with her parents, five brothers, and baby sister, Haguewood exchanged letters with Donald, and soon began a wide correspondence with friends and acquaintances. ${ }^{34}$

Haguewood's increasing communication skills aided her in all her studies. In mathematics, according to her teacher, her work showed that she "needed only language" to express the knowledge already within her. Haguewood used a number slate sent to her by William Wade, a philanthropist from Oakmont, Pennsylvania. Wade had first become interested in Helen Keller in the 1880s and subsequently expanded his attention to the welfare of all deaf-blind children in the United States. ${ }^{35}$

Haguewood's happiest class hours, Donald avowed, were spent in the sewing room. "She has learned to sew on the ma-

33. Vinton Eagle, 3/27/1896; Fifty-Seventh Annual Report (Boston, 1889), 133. Progress toward a unified code was finally made in 1932 with the adoption of Standard English Braille, Grade 2. See McGinnity, Seymour-Ford, and Andries, "Books for the Blind."

34. Cedar Rapids Evening Gazette, 3/19/1898; Adams County Union, 7/16/1896.

35. Vinton Eagle, 3/27/1896. William Wade (1837-1912) published a monograph, The Deaf-Blind, in 1901. He credited Donald and her "great-heartedness" for inspiring him to reach out to all known deaf-blind children in the United States. Vina C. Badger, "How Mr. Wade Became Interested in the Blind-Deaf," The Association Review 8 (1906), 371-73. Upon Wade's death, a tribute by Helen Keller appeared in Outlook for the Blind 7 (Oct. 1913), 47. 
chine and no dignitary of this great state of ours has a greater sense of personal importance than has Linnie when seated at her machine." During the school year, Haguewood constructed three articles of clothing, including a cotton dress for herself. The only help she received was placing the patterns on the fabric, and her teacher boasted that her work would compare favorably with that of any 16-year-old girl who could see and hear. ${ }^{36}$

In showing an attraction to the domestic arts and femininity, Haguewood followed typical patterns and expectations of the day. Accounts by herself and others highlighted her appreciation of fine clothes and adornment and the care she took with her wardrobe. Donald credited the power of "a fresh apron, clean collars and cuffs, and a few curls in her hair" to lift her pupil's spirits. Donald also noted Haguewood's interest in what others wore. She recognized friends' attire by touch and, her teacher reported, formed an accurate impression of people through their habits of dress. Press accounts lauded Haguewood's charming manners, her meticulously crafted handwork, and her domestic interests. "Housework is [a] delight," the Saint Paul Globe claimed on her behalf. 37

In addition to Haguewood's femininity and domestic accomplishments, Donald emphasized her pupil's sympathy and compassion, demonstrated through her friendships with other students and her concern for those who suffered in any way. Generosity and empathy were traits especially singled out by society as desirable in those with disabilities as a means of showing their moral development and the ability to transcend their "affliction" in the service of others. Reports on Bridgman and Keller showcased these qualities, including numerous examples of their generosity to others less fortunate. ${ }^{38}$

36. Vinton Eagle, 3/27/1896. See also Adams County Union, 7/16/1896.

37. Des Moines Daily News, 2/18/1898; Broad Ax (Salt Lake City, UT), 7/3/ 1897; Saint Paul Globe, 11/8/1897. See also Sioux City Journal, 12/24/1897; Des Moines Daily News, 2/18/1898; and Omaha Daily Bee, 11/18/1897. Letters by Haguewood reprinted in the Sioux Falls Press, 3/7/1897, and Cedar Rapids Evening Gazette, 3/19/1898, illustrate her enjoyment of jewelry and flowers.

38. See, for example, Ninth Annual Report (Boston, 1841), 38; Fifty-Seventh Annual Report (Boston, 1889), 100; and Klages, Woeful Afflictions, 7, 131. 
At the Iowa College for the Blind, Donald reported, Haguewood was particularly close to a student named Alice, who had lost two fingers and with whom she loved to share her treats and spend parts of her holidays. Donald also related an incident in which a classmate of Haguewood's sprained her ankle. Distressed by the mishap, Haguewood found comfort in a psalm in her prayer book, which entreated "that the bones which Thou hast broken may rejoice," and eagerly shared the verse with her friend. Another acquaintance, whom Haguewood had met while visiting the orphanage in Council Bluffs, needed to have a leg amputated; Haguewood was so moved to empathize that she offered up all her savings, intended for a music box for herself, to buy "poor Maggie a cork leg." 39

The perceived role of people with disabilities in inspiring others to live up to their own ideals of behavior formed a theme in media accounts about Haguewood. "No person who possesses the eyesight, hearing and the power of conversation and all of these blessings should forget this case, and no matter what their trouble may be, they should stop and make comparison before they complain too bitterly," declared the Cedar Rapids Evening Gazette. "It requires courage to brave afflictions in life and surely this girl has demonstrated her bravery and it behooves each and all in distress and with burdens of various kinds upon them to struggle on, letting the light of hope burn brightly on with patience and humility and a belief in the rewarded justice, and do the best they can." 40

In response to questions about Haguewood's "mission in life," Donald asserted that her pupil's life was full of usefulness. "Where can you find such another example of patient perseverance; where can you find one who has worked more faithfully; who has taken up the burden laid upon them as cheerfully and performed the duties required of them with the painstaking care of this girl?" she asked. "Her development has been a rounding out of her character, a growth in every direction." 41

39. Adams County Union, 7/16/1896; Donald, "Linnie Haguewood," 46; Omaha Daily Bee, 11/18/1897.

40. Cedar Rapids Evening Gazette, 3/19/1898.

41. Adams County Union, 7/16/1896. 
IN NOVEMBER 1896 Donald and Haguewood, now age 17, commenced a round of travel to regional schools for the deaf. The goal was to supplement Haguewood's previous experience of associating primarily with blind students and to place her into direct contact and communication with others who were deaf. Donald, too, would benefit by familiarizing herself with methods of deaf education. The pair first made brief visits to the Iowa School for the Deaf in Council Bluffs and the Nebraska Institute for the Deaf and Dumb in Omaha. Both schools' newspapers covered the visits, treating Haguewood as a star. "Her powers excited considerable wonder and admiration," reported the Deaf Hawkeye. "All day she is flocked about by little children who converse with her by the manual alphabet. She takes their sayings by the touching of their fingers." The Nebraska Mute Journal likewise fixed on the remarkable: "It is marvelous how much a person afflicted thus can do. ... When she gets hold of a new idea, she will follow it up to master it, and will not abandon it till she does know it. We fell in love with the deaf girl, and want her to come back again. . . To be deaf seems to us to be nothing, since we have seen poor, sweet-faced Linnie." 42

Haguewood's next and longest visit was at the South Dakota School for Deaf Mutes in Sioux Falls, where about 50 students were enrolled. Teacher and pupil arrived at the beginning of December and remained in residence for several months. While there, Haguewood was able to interact closely with the school's skilled deaf communicators. ${ }^{43}$ In January 1897 a Sioux Falls Press writer visited the school and spent a few hours in the company of Haguewood and Donald. "Miss Linnie can . . . talk with her fingers as rapidly as an ordinary child can with the tongue," he marveled, detailing her facility with writing, doing sums, crocheting, telling time, and recognizing acquaintances by touch-

42. Vinton Eagle, 11/20/1896 (reprinted from Deaf Hawkeye); Daily Iowa Capital, 12/12/1896 (reprinted from Nebraska Mute Journal). See also Sioux City Journal, 11/15/1896.

43. Sioux Falls Evening Argus-Leader, 12/3/1896; Donald, "Linnie Haguewood," 43; "South Dakota School for Deaf Mutes," Fifth Biennial Report of the State Board of Commissioners of Charities and Corrections for the State of South Dakota (Pierre, SD, 1898), 165. 
ing their hands. "She enjoys company very much and is always pleased to show her accomplishments." 44

At the end of February, the students and teachers of the public schools of Sioux Falls presented Haguewood with the gift of a typewriter. The machine was the newest model Smith Premier, a regular typewriter with no special features for the blind or deaf. In just a few days, the press reported, Haguewood had mastered typing and sent a letter of thanks to her donors, expressing, as she did in all her public correspondence, gratitude and delight.

Sioux Falls, S.D., March 5, 1897.

My dear friends: I want to thank you for your beautiful present. I want the children to know that it has made me very happy! I laugh all the time because it is such fun to write with a typewriter.

Everybody is so good-so very good - to me. Yesterday the ladies of Sioux Falls gave me a nice new ring. It has five sets: three are blue and two are white. They are kind to give it to me.

I shall always love the good people of Sioux Falls, and when I go back to Vinton I shall write to them with my typewriter.

Your grateful and happy friend.

$$
\text { Linnie Haguewood } 45
$$

At the request of Sioux Falls Argus-Leader editor Charles Day, Haguewood typed a letter, unaided, in his presence without, he observed, a single misspelled word. In it, she again conveyed her thanks to the people of Sioux Falls, wrote of her friendship with deaf school superintendent James Simpson ("He teases me when I go to see him in his office"), and described how much she liked South Dakota. "The blizzards blow at me and make me laugh. They are gone now. Spring made them go away. Spring means March, April and May. I shall go to my home in Delaware, Iowa, when happy June comes. They will be glad to see me." 46

While at the South Dakota school, Haguewood practiced learning to speak, a process she had begun at Vinton. Voice

44. Sioux Falls Press, 1/10/1897.

45. Reprinted in Sioux Falls Press, 3/7/1897. See also Waterloo Daily Courier, 3/13/1897.

46. Reprinted in Broad Ax (Salt Lake City, UT), 7/3/1897. James Simpson (1855-1903) was superintendent of the South Dakota School for Deaf Mutes from 1881 to 1903 and was himself deaf. The Transcendent Territory: The Minds, Hearts and Hands Behind the Unique Deaf and Hard of Hearing Culture of South Dakota (Sioux Falls, SD, 2000), 7-11. 
articulation, or oralism, had become an increasingly popular though controversial and much debated method in deaf education. The debate pitted the oralists against the manualists, who favored the use of sign language and the manual alphabet. In advocating the teaching of spoken language to deaf people, oralists touted the advantages of integration with the broader, hearing society. Manualists emphasized the continuous struggle and uncertain results of learning speech at the expense of the abundant social, cultural, and educational benefits derived from use of manual communication. 47

In 1890 Helen Keller had begun voice articulation lessons after finding out about a Norwegian deaf-blind girl, Ragnhild Kaata, who had learned to speak. Keller's efforts to speak orally would be a lifelong, labor-intensive process. Alexander Graham Bell, a friend and mentor of Keller, was a staunch proponent of oralism and, consequently, a problematic figure among the deaf community. Bell wanted to integrate deaf people into hearing society as much as possible, fearing the creation of a "deaf variety of the human race." Signs, he claimed, were a primitive form of language that should be discouraged. In 1890 Bell founded the American Association to Promote the Teaching of Speech to the Deaf and served as its first president. Samuel Gridley Howe, too, regarded sign language as primitive, believing in the superiority of alphabetic-based language. For deaf-blind instruction, he used raised letters and, subsequently, the manual alphabet. 48

Donald believed in oral instruction for Haguewood, but only as a supplement to manual communication. She did not support exclusive oralism or the use of the method for all deaf

47. For historical perspective on oralism and manualism, see Douglas C. Baynton, Forbidden Signs: American Culture and the Campaign Against Sign Language (Chicago, 1996); John Vickrey Van Cleve and Barry A. Crouch, A Place of Their Own: Creating the Deaf Community in America (Washington, DC, 2002); and Susan Burch, Signs of Resistance: American Deaf Cultural History, 1900 to World War II (New York, 2002).

48. Nielsen, Beyond the Miracle Worker, 104; Nielsen, Radical Lives of Helen Keller, 2; Gitter, The Imprisoned Guest, 40-41, 81; Klages, Woeful Afflictions, 81. For more on Bell's (ungrounded) fear that deaf couples' marrying in large numbers would result in a deaf race, see Alexander Graham Bell, Memoir Upon the Formation of a Deaf Variety of the Human Race (Washington, DC, 1884); Baynton, Forbidden Signs, 30-31. 
students. ${ }^{49}$ The speech learning process for Haguewood involved placing her fingers on the throat and mouth of her teacher while Donald simultaneously pronounced a letter or combinations of letters and formed them upon Haguewood's hand, which Haguewood in turn attempted to pronounce. At first, Donald reported, Haguewood resisted the project, but the idea that she would be able to communicate with many more people by using her voice eventually led her to willingly enlist in the effort. Teacher and student painstakingly proceeded sound by sound, learning the facial movements of each. ${ }^{50}$ Learning to speak clearly would be an ongoing challenge. A reporter who interviewed Haguewood and Donald in August 1897 near Corning, Iowa, where the two were staying with friends of Donald's, noted that some of Haguewood's words were intelligible, including his own name and Donald's, while others were only understood as yet by her teacher. ${ }^{51}$

Haguewood returned to school in Vinton in the fall of 1897. Several of her letters from those months were reprinted in the press. She expressed interest in the lives of her friends and described her daily activities, including her studies, picnics attended, and visits received. She conveyed gratitude to her friends in Sioux Falls for the gift of a desk and to Bernard Murphy, who had provided train passes for a trip home at Christmas. Her brother Zed, she related, had taken her, her sister Charlotte Mae, and Donald sleigh riding, after which they made popcorn balls. She had received numerous Christmas presents, all of them "beautiful." 52

49. "I feel that signs have been no disadvantage to [oral pupils] in the acquirement of speech and have added much to their general development," Donald wrote in 1906 as superintendent of the South Dakota School for Deaf Mutes. "South Dakota School for Deaf Mutes," Ninth Biennial Report of the State Board of Charities and Corrections for the State of South Dakota (Huron, SD, 1906), 93.

50. Cedar Rapids Evening Gazette, 6/15/1899; Los Angeles Times, 8/16/1908.

51. Adams County Free Press, 8/12/1897.

52. Recipients of Haguewood's letters included home economist Mary Moody Pugh of Omaha (9/30/1897, reprinted in Waterloo Daily Courier, 4/1/1899); Cedar Rapids resident Francis Wynn (10/6/1897, reprinted in Cedar Rapids Evening Gazette, 3/19/1898); and Bernard Murphy (1/13/1898, reprinted in Cedar Rapids Evening Gazette, 1/28/1898). 
In February Haguewood, Donald, and Murphy visited the state legislature in Des Moines to personally appeal for continued funding of Haguewood's education. Money from the fund Murphy and his committee had raised from Iowans had paid for the 1895 and 1897 school years; the $\$ 500$ allocated by the Iowa legislature had been expended in 1896. Legislators were now asked to appropriate $\$ 1,000$ for two more years. While at the capitol, Haguewood met with newly elected governor Leslie Shaw and a number of legislators. Donald noted the ease with which the young woman adapted to new situations, picking up "little airs and added graces." Haguewood was the center of attention, noted the press, and "it will be a surprise if there is a vote against the appropriation." Indeed, the otherwise generally stingy legislature readily granted the requested funds. ${ }^{53}$

HAGUEWOOD'S TRAVEL EXPERIENCES and her studies kindled a desire to "go every place and see everything," her teacher wrote. Over the next few years, that wish was, to a degree, realized. "She almost seems to see the very landscapes from the car windows, so complete an impression does she get of the things around her while traveling," stated one media report. ${ }^{54}$

In June 1898 Haguewood and Donald attended the TransMississippi Educational Convention in Omaha. There, they took part in a session on the education of deaf and blind children. While in Omaha Haguewood also participated in the TransMississippi and International Exposition, a giant fair that boasted some 4,000 exhibits and attracted more than 2.5 million visitors. The Smith Premier Typewriter Company employed Haguewood to demonstrate her typing skills for a few hours each day at the company's booth in the Liberal Arts Building, where all types of modern appliances were exhibited. ${ }^{55}$ Helen Gillespie,

53. Des Moines Daily News, 2/18/1898; Milford Mail, 2/24/1898. See also Waterloo Daily Courier, 2/18/1898; Aurner, History of Education in Iowa, 5:48; 1898 Laws of Iowa, chap. 126, sec. 1.

54. Donald, "Linnie Haguewood," 43; Waterloo Daily Courier, 4/1/1899.

55. "Miscellaneous," American Annals of the Deaf 43 (1898), 331; Omaha World Herald, 6/3/1898; "A Deaf, Dumb, and Blind Expert Typist," Illustrated Phonographic World 14 (Sept. 1898); "Publisher's Notes," The Menorah: A Monthly Magazine for the Jewish Home 25 (Nov. 1898), 335-36. The Exposition was held from June 1 to November 1, 1898. 


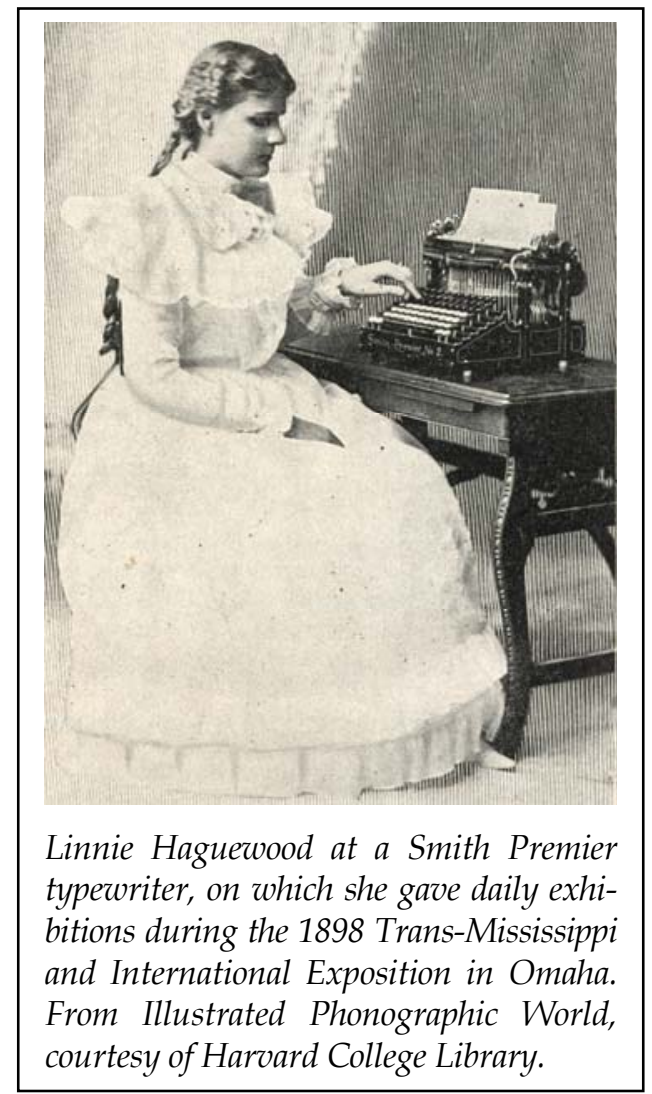

who, with her husband, John (former principal of the Nebraska Institute for the Deaf), hosted Haguewood and Donald, wrote of the admiring attention Haguewood attracted at the booth with her "knowledge, ready answers, and pleasing manners." Haguewood used her earnings to personally select and purchase white slippers and a wicker rocker. ${ }^{56}$ The nuances of being an object of public display went unexplored.

Later in the summer of 1898 Haguewood and Donald traveled to Columbus, Ohio, to attend the Convention of American

56. Reprinted in Vinton Eagle, 7/12/1898. John A. Gillespie headed the Nebraska Institute for the Deaf and Dumb from 1878 to 1897 and then began a private school for deaf pupils in Omaha. Gillespie, "History of the Nebraska School for the Deaf and Dumb," in Histories of the American Schools for the Deaf, 1817-1893, ed. Edward Allen Fay, 3 vols. (Washington, DC, 1893), 2:9; Waterloo Daily Courier, 4/1/1899. 
Instructors of the Deaf. The trip was arranged and financed by William Wade, the prominent supporter of deaf-blind education, whom they were meeting for the first time. At the convention, Donald spoke of her work with Haguewood, and again Haguewood displayed her skills to an engaged audience. ${ }^{57}$ Wade wrote to Murphy upon his return from the convention:

You may say to Iowa that Linnie Haguewood and Miss Donald simply captured the entire body. Even those who longest and most thoroughly knew and appreciated Helen Keller devoted themselves constantly to Linnie. ... And so complete was the general interest in her that Miss Donald came to surrendering her with the utmost confidence. I may add that Miss Donald's simplicity and absence of all notions that she had done anything wonderful or exceptional, only added to the universal opinion that there could not possibly be a better teacher of the deaf-blind. Iowa has rendered a great service to the interests of the deaf-blind by sending Miss Donald and Linnie to this convention. ${ }^{58}$

For the 1898-99 school year, Haguewood and Donald returned to the South Dakota School for Deaf Mutes at the invitation of Superintendent Simpson. In January 1899 Haguewood wrote to Francis Wynn, a Cedar Rapids resident, whom she and her teacher had befriended two years earlier, describing her Christmas and thanking Wynn for a picture he had sent her, which she kept on her dresser. She prized her new music box, received from William Wade, had delighted in dancing at two school parties, and was anticipating sledding. Haguewood was also enjoying reading her new Christmas stories, raised-print books of the Bible, and other "point books" provided by Wade. In school, she was studying history, geography, language, and arithmetic. ${ }^{59}$

In June 1899 Haguewood and Donald began an extended trip, traveling by train to Duluth, Minnesota, and by steamer to Buffalo, New York, with a final destination of Northampton, Massachusetts, to attend the Convention of the American Asso-

57. Vinton Eagle, 8/5/1898, 8/9/1898; Semi-Weekly Cedar Falls Gazette, 8/16/ 1898; "Fifteenth Meeting of the Convention of American Instructors of the Deaf," American Annals of the Deaf 43 (1898), 276.

58. Reprinted in Vinton Eagle, 8/9/1898.

59. Reprinted in Cedar Rapids Evening Gazette, 1/28/1899. 
ciation to Promote the Teaching of Speech to the Deaf. They were interviewed en route, while waiting to change trains in Cedar Rapids. Haguewood's spoken words of greeting and her response to a question about her travel plans came slowly, but quite plainly, the reporter observed. ${ }^{60}$

At the conference, Haguewood met Alexander Graham Bell, in attendance as president of the association. She had also been looking forward to meeting Helen Keller, who was preparing to take final examinations for enrollment at Radcliffe College. Corresponding with William Wade shortly before the planned meeting, Keller referred to a letter of Haguewood's that Wade had recently sent her. It "interested me very much," Keller wrote. "It seemed to show spontaneity and great sweetness of character. I was a good deal amused by what she said about history. I am sorry she does not enjoy it; but I too feel sometimes how dark, and mysterious and even fearful the history of old peoples, old religions and old forms of government really is." 61 In her letter, Haguewood had mentioned disliking history because "it is about such old people." 62 Whether the meeting between Keller and Haguewood actually took place is unknown.

HAGUEWOOD turned 20 in October 1899. That fall she entered the teacher training department of the Iowa State Normal School in Cedar Falls, the school Donald had attended, and embarked on a regular course of study. 63 This was Haguewood's first experience in a school for seeing and hearing students. Bernard Murphy informed the Board of Control of the State Institutions of Iowa that Haguewood had (as worded by the Waterloo Daily Courier) "reached the age and the point in her education where it is desirable to have her mingle with an older class of associates than she meets at the College for the Blind at Vinton." The \$35 allotted quarterly to each resident of the College for the Blind

60. Vinton Eagle, 6/9/1899; Cedar Rapids Evening Gazette, 6/15/1899; Sioux Falls Daily Argus-Leader, 6/16/1899.

61. Helen Keller to William Wade, 6/5/1899, in Keller, The Story of My Life, 255-56.

62. Quoted in Wade, The Deaf-Blind, 32.

63. Vinton Eagle, 10/3/1899; Semi-Weekly Cedar Falls Gazette, 10/24/1899. 
would continue, and the $\$ 5$ fee regularly charged to students at the Iowa State Normal School was waived for Haguewood (as it was for returning Spanish-American War veterans). ${ }^{64}$

For the first part of the school year, Donald accompanied Haguewood to her classes and acted as her interpreter. ${ }^{65}$ Education professor George W. Walters, in full sentimental mode, lauded the partnership between student and teacher: "I used to sit in church behind Linnie Haguewood and see her teacher's finger tips touching the palm of her hand; and Linnie's face would light up with joy and radiant hope. And I said 'Thank God for a State that makes a special appropriation to educate such a child.'" 66

In April 1900 the Iowa legislature again approved \$1,000 for two more years of education for Haguewood. "It was largely through Mr. Murphy's efforts that the appropriation was secured," the Cedar Rapids Evening Gazette reported, "and this is one of the items of expenditure that the legislature never wrangles about." 67

Meanwhile, at the beginning of 1900, Donald was appointed superintendent of the newly created South Dakota School for the Blind in Gary. She accepted the position with the agreement that Haguewood could continue as her student. Thus, after completing the year at the normal school and spending the summer with her family, Haguewood entered the South Dakota School for the Blind in October 1900. The 1900-1902 biennial report listed 29 students enrolled at the school. Haguewood's mother and younger siblings accompanied her to Gary and remained there until Haguewood completed her education in 1903. ${ }^{68}$

64. Waterloo Daily Courier, 9/23/1899; "Report on Educational Institutions," First Biennial Report of the Board of Control of State Institutions of Iowa (Des Moines, 1900), 271.

65. Waterloo Daily Courier, 9/23/1899.

66. G. W. Walters, "Peculiar Children," in Proceedings of the Forty-Ninth Annual Session of the Iowa State Teachers Association (Des Moines, 1904), 142.

67. 1900 Laws of Iowa, chap. 173, sec. 1, p. 123; Cedar Rapids Evening Gazette, 2/23/1901.

68. Adams County Free Press, 2/22/1900; Waterloo Semi-Weekly Courier, 9/14/ 1900; Wade, The Deaf-Blind, 11; Gary Inter State, 10/12/1900; Des Moines Daily Leader, 10/31/1901; "South Dakota School for the Blind," Seventh Biennial Report of the State Board of Commissioners of Charities and Corrections for the State of 


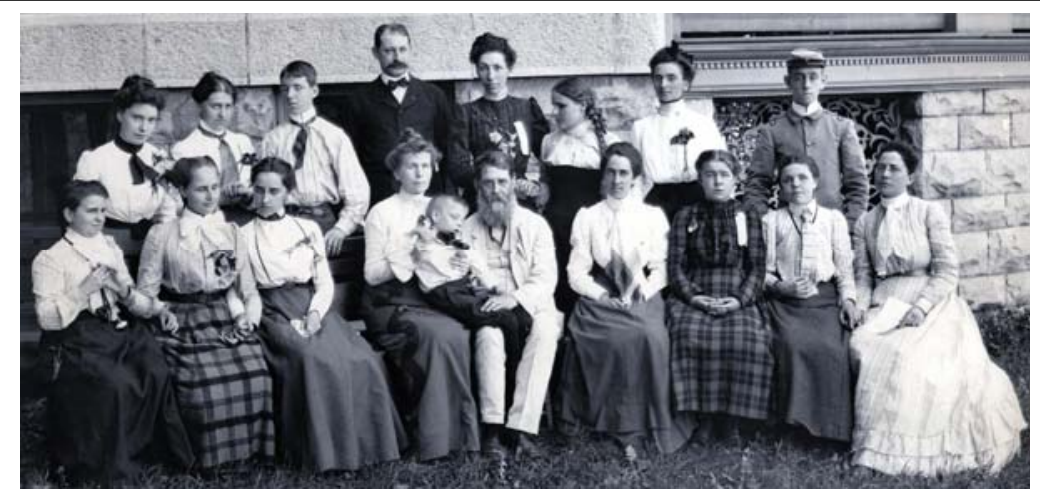

Linnie Haguewood stands third from the right facing Dora Donald in this photograph taken in 1901 at the gathering of deaf-blind students and their teachers in Buffalo, New York. William Wade is seated at front center. Photo courtesy Perkins School for the Blind, Watertown, Massachusetts.

In the summer of 1901, after her first year at the Gary school, Haguewood traveled with Donald to Buffalo, New York, to attend a first-ever formal gathering of deaf-blind students, arranged by William Wade and held in conjunction with the convention of the American Instructors of the Deaf. Eight students were in attendance with their teachers. By all accounts, the convention proved valuable, allowing the students to interact and their educators to compare teaching methods and experiences. While in Buffalo, the conference goers visited the attractions of the Pan-American Exposition, which had opened in May 1901, and also nearby Niagara Falls. ${ }^{69}$

On September 6, 1901, Buffalo became the site of national tragedy. While at the Pan-American Exposition, President Wil-

South Dakota (Aberdeen, SD, 1902), 151. Until the opening of the school in Gary, the state had an arrangement to send its students to the Iowa College for the Blind. For a history of the Gary school, see Marjorie A. Kaiser, "History of the South Dakota School for the Blind and Visually Impaired: The First Century" (Ed.D. diss., University of South Dakota, 1999).

69. "Sixteenth Meeting of the Convention of American Instructors of the Deaf," American Annals of the Deaf 46 (1901), 350-51; Des Moines Daily Leader, 10/31/ 1901. Besides Haguewood, the conference attendees were Edith Thomas, Willie Elizabeth Robin, and Thomas Stringer of the Perkins Institution; Orris Benson, Katie McGirr, and Catherine Pederson of the New York Institution for the Deaf; and Leslie Oren of the Ohio Institution for the Deaf. 
liam McKinley was shot. He died eight days later. Back at the School for the Blind in Gary for the recently commenced fall term, Haguewood attended a church service commemorating the dead president. Also present were Donald and Haguewood's deaf tutor, Jessie Beardsley. Donald's role as interpreter drew comment from the local paper. "One of the most pathetic sights we ever witnessed occurred in the Methodist church in Gary last Sunday morning," the report began, and then described how Donald, seated between the two women, provided one hand to each as she spelled out the proceedings. "The recipients were intent in their attention," the article continued, "and evidently received full benefit of the very interesting service and sermon." 70

In conjunction with her academic studies at the South Dakota School for the Blind, which included reading, spelling, English composition, language, geography, U.S. history (steadily gaining in appeal), and mathematics, Haguewood learned to operate the stereotype maker. The machine, provided by Wade, was used to copy materials in Braille. Haguewood quickly gained proficiency, Donald reported. ${ }^{71}$ The stereotype maker had keys like a typewriter and printed characters in Braille onto brass plates. After making a plate, Haguewood proofread it with her fingers, hammering down any misplaced dots. She placed moistened sheets of heavy white paper over the brass sheets and then between rubber sheets and ran all through a roller press. When the pages dried, she bound them together. Among Haguewood's major stereotyping achievements were novelist Laurence Sterne's The Story of Le Fevre, extracted from Tristram Shandy, and A Sentimental Journey through France and Italy. Forty copies were made and sent to schools for the blind. ${ }^{72}$

IN 1903, after finishing her education at the South Dakota School for the Blind, Haguewood moved with her family to Los Angeles, California, where her father had found work as a carpenter. The remaining funds set aside for Haguewood's education were

70. Gary Inter State, 9/20/1901.

71. Donald, "Linnie Haguewood," 43, 46; Cedar Rapids Evening Gazette, 2/23/ 1901; Waterloo Daily Courier, 9/25/1902.

72. Tazewell (VA) Republican, 10/1/1903; Los Angeles Times, 8/16/1908. 
returned to Iowa's state treasury. ${ }^{73}$ In 1908 a Los Angeles Times reporter who visited the Haguewood home described a closeknit and supportive family. Haguewood's parents and six siblings, he reported, "all think the world of her, understand her, and take keen joy in being able to talk with her through the sign-language." Although the reporter found Haguewood's spoken words difficult to understand, he observed that her brother readily comprehended them. Haguewood's mother employed an additional means of communication: "No matter in what part of the house the young woman is, her mother calls her by tapping lightly '1---5,' on the floor. No matter how much noise there may be, she catches the vibrations and answers the message." Haguewood performed household chores and continued to crochet and do needlework. She made some of her own clothes and went shopping to select dress goods, ever fastidious about the weave and fabric. The reported described in detail Haguewood's stereotype maker and her skill at copying books for blind readers, and he noted her fascination with machinery and how it worked. She had studied the automobile, telephone, and phonograph and was interested in keeping up with inventions and scientific topics. Notably, the reporter directed his questions about Haguewood to others rather than to Haguewood herself. "And is Linnie Haguewood happy?" he asked. "The ready and immediate answer of her closest friends is 'Yes.' She has a lovable disposition and usually wears a sunny smile." 74

Haguewood spent the remainder of her life in Los Angeles, out of the public eye. In her later years, she resided with her younger brother Rollin, a retired pharmacist in the U.S. Navy, and then moved next door to live with her sister. Her greatniece Jeanie Hickerson remembered visiting Haguewood as a child. "She always identified me by gently feeling my face and arms, and then spelling out my name on her fingers." Hicker-

73. Gary Inter State, 11/20/1903; Iowa Postal Card (Fayette, Iowa), 5/19/1904; Los Angeles City Directories, 1909, 1915; Manuscript Population Schedule, Los Angeles, Los Angeles Co., CA, in U.S. Department of Commerce, Bureau of the Census, Thirteenth Census of the United States, 1910, National Archives Microfilm Publication T624, roll 79, sheet 12A.

74. Los Angeles Times, 8/16/1908. 
son recalled coming to visit once with her grandfather, who was Haguewood's older brother Clem. "He shuffled his feet in a special way that he had always done when he came near her, and she could feel the vibration and identified him. I remember her face brightening up and her joyous voice calling out 'Clem!'” Linnie Haguewood died April 18, 1967, in Los Angeles. She was 87 years old. ${ }^{75}$

For Dora Donald, the experience of being Haguewood's teacher and the reputation gained thereby continued to open professional doors. In 1903 she was appointed James Simpson's successor as superintendent of the South Dakota School for Deaf Mutes, and in 1907 she returned to Gary as superintendent of the South Dakota School for the Blind, serving until 1909. In July 1907, at age 38, she married LeRoy August Humbert, who had taught violin and small instruments at the School for the Blind. She remained active in public service until her death on September 3, 1934, in Gary. ${ }^{76}$

Donald's influence and that of the media were instrumental in shaping Haguewood's public persona. Prevailing Victorian attitudes toward disabilities and gender and the media's pursuit of their own agendas all played their part in the construction of her identity. Societal expectations and conventions guided the content and tone of Donald's reports and the letters written by Haguewood herself, many of which were reprinted in the press. As with Bridgman and Keller, press coverage commonly depicted Haguewood in one-dimensional ways, focusing on the remarkable, the pathetic, and the sentimental, leaving the complex and rich realities of her life unexplored. An examination of the available material is nonetheless valuable. Haguewood's story discloses the options possible for students with disabilities beyond the sphere of the prestigious eastern institutions and illuminates the context in which she lived her life.

75. Fry and Hickerson, Genealogy of the Family of Clem Frank Haguewood, 20P; Le Mars Semi-Weekly Sentinel, 2/13/1923; Jeanie Hickerson to author, 5/8/2011.

76. Eighth through eleventh biennial reports of the State Board of Commissioners of Charities and Corrections for the State of South Dakota (1904-1910); Gary Inter State, 8/2/1907; Historical Collections of Deuel County, 389. 